
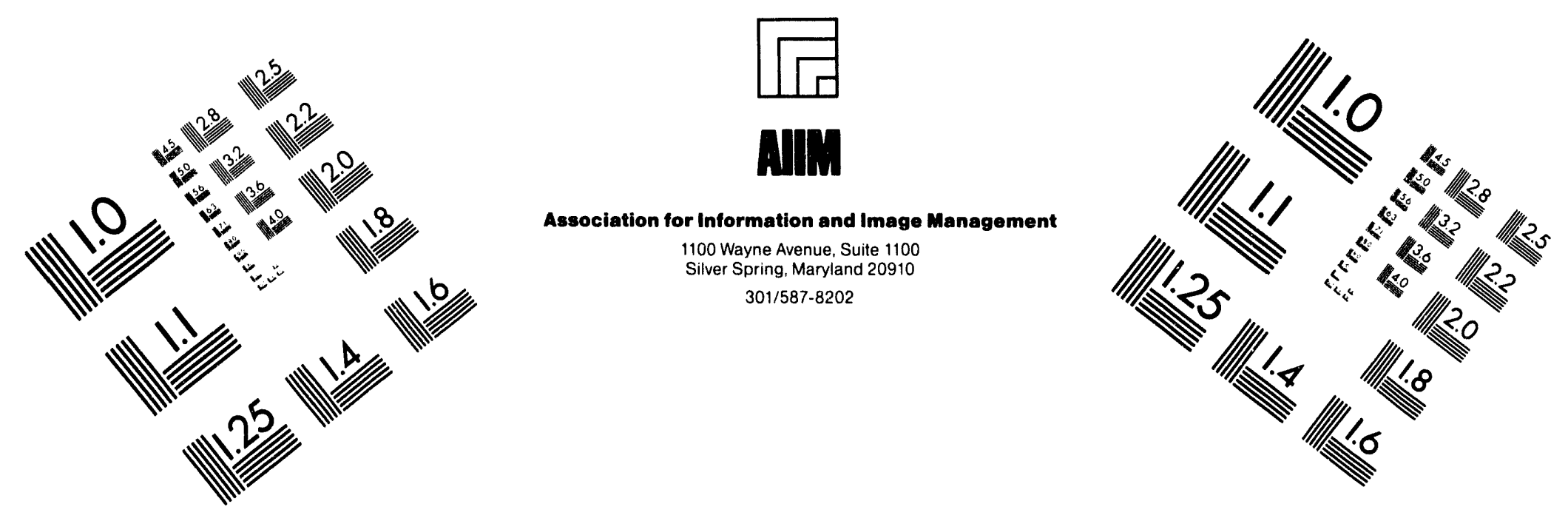

\title{
Centimeter
}

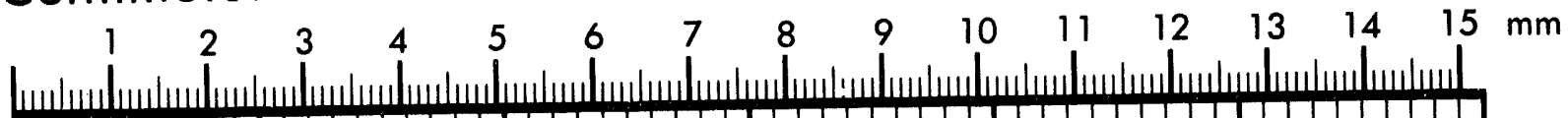

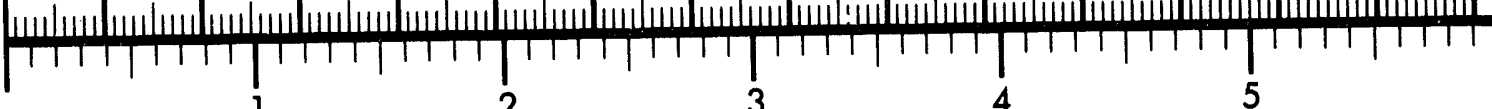

Inches
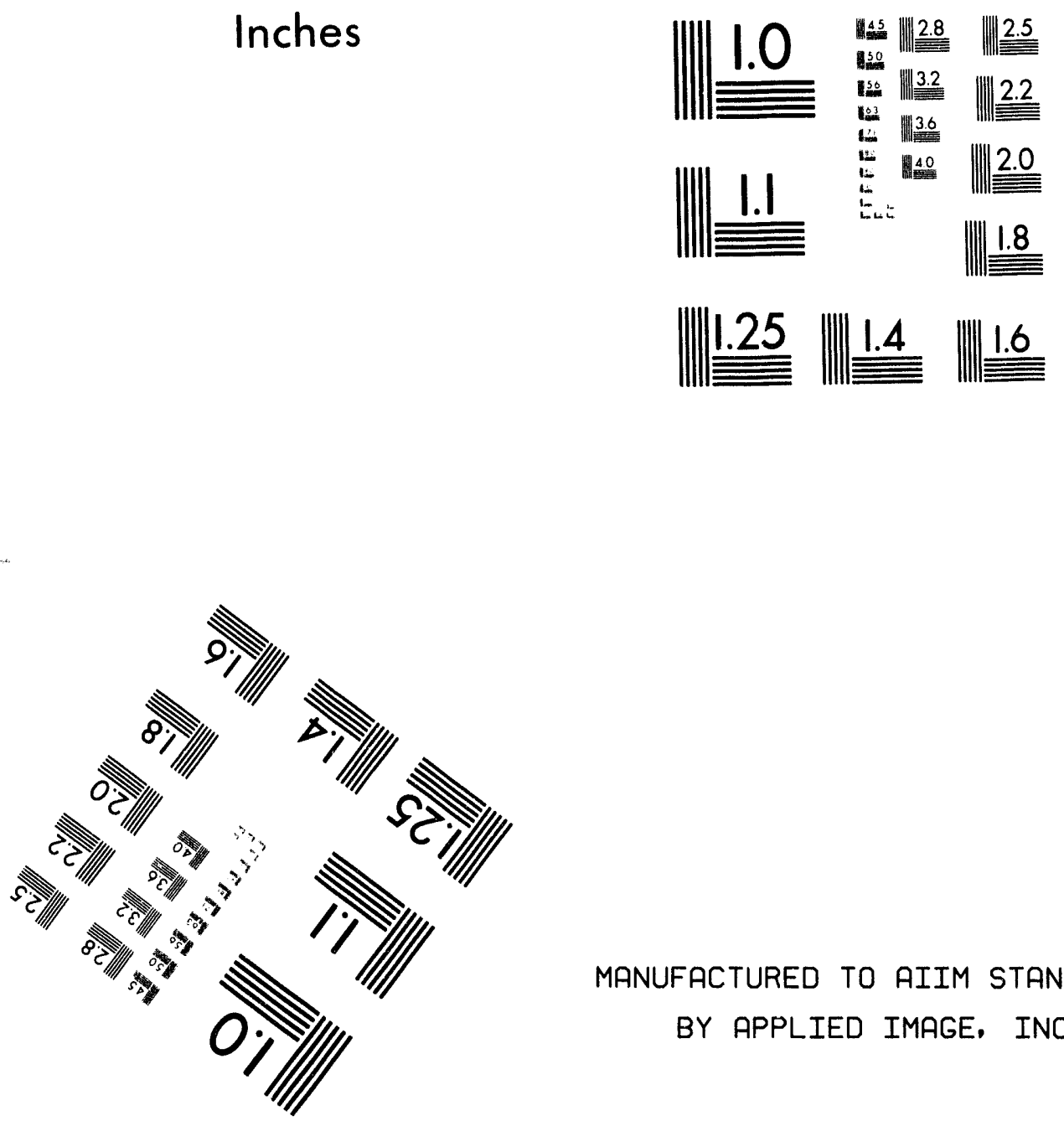

MANUFACTURED TO AIIM STANDARDS

BY APPLIED IMAGE, INC.

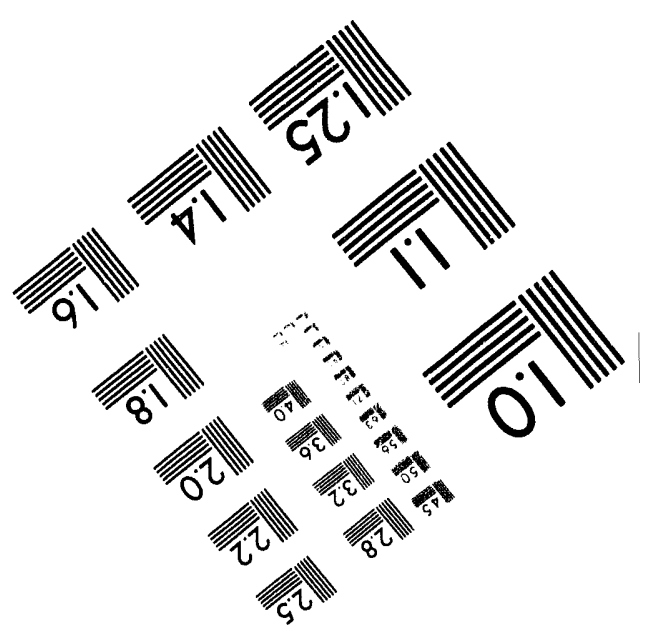



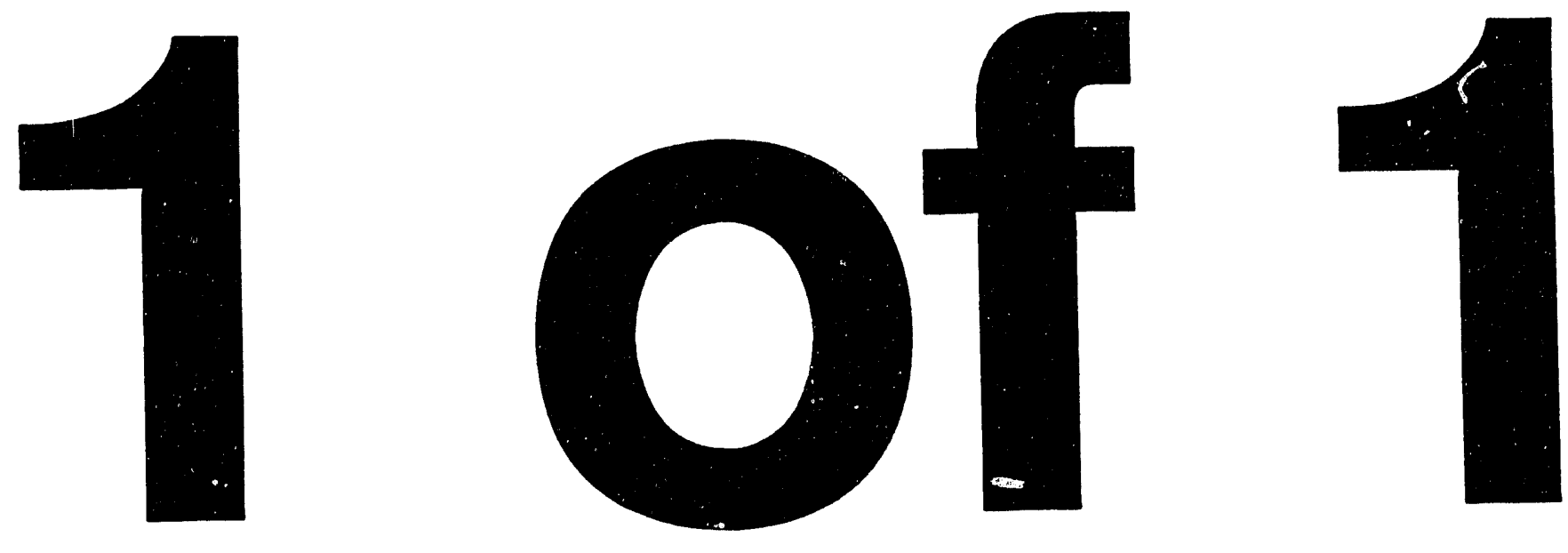


\section{Impact Fracture Behavior of HT9 Duct}

Prepared for the U.S. Department of Energy Office of Environmental Restoration and Waste Management

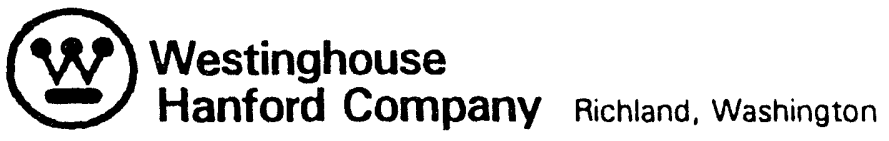

Hanford Operations and Engineering Contractor for the

U.S. Department of Energy under Contract DE-AC06-87RL10930

Copyright Licenes By acceptance of this article, the publisher and/or recipient acknowledges the

U.S. Government's right to retain a nonexclusive, royalty-free license in and to any copyright covering this paper.

Approved for Public Release 
WHC-SA-2512-FP

\title{
Impact Fracture Behavior of HT9 Duct
}

\author{
F. H. Huang
}

Westinghouse Hanford Company

D. S. Gelles

Pacific Northwest Laboratory

Date Published

July 1994

Prepared for the U.S. Department of Energy

Office of Environmental Restoration and

Waste Management

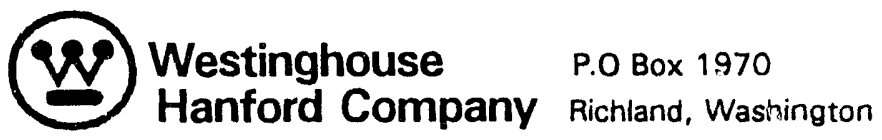

Hanford Operations and Engineering Contractor for the

U.S. Department of Energy under Contract DE 1C06-87RL10930

Copyright Licenee By acceptance of this article, the publisher and/or recipient acknowledges the

U.S. Government's right to retain a nonexclusive, royalty-free license in and to any copyright covering this paper 
LEGAL DISCLAIMER

This report was prepared as an account of work sponsored by an agency of the United States Government. Neither the United States Government nor any agency thereof, nor any of their employees, nor any of their contractors, subcontractors or their employees, makes any warranty, express or implied, or assumes any legal liability or responsibility for the accuracy, completeness, or any third party's use or the results of such use of any information, apparatus, product, or process disclosed, or represents that its use would not infringe privately owned rights. Reference herein to any specific commercial product, process, or service by trade name, trademark, manufacturer, or otherwise, does not necessarily constitute or imply its endorsement, recommendation, or favoring by the United States Government or any agency thereof or its contractors or subcontractors. The views and opinions of authors expressed herein do not necessarily state or reflect those of the United States Government or any agency thereof.

This report has been reproduced from the best available copy.

Printed in the United States of America

DISCLM-2.CHP (1-91) 
IMPACT FRACTURE BEHAVIOR OF HTI DUCT

\begin{abstract}
Ferritic alloys are known to undergo a ductile-brittle transition as the test temperature is decreased. This inherent problem has 1 imited their applications to reactor component materials subjected to low neutron exposures. However, the excellent resistance to void swelling exhibited by these alloys has led to choosing the materials as candidate materials for fast and fusion reactor applications. Despite the ductile-brittle transition problem, results show that the materials exhibit superior resistance to fracture under very high neutron fluences at irradiation temperatures above $380^{\circ} \mathrm{C}$. Impact testing on FFTF duct sections of HTg indicates that HTg ducts have adequate fracture toughness at much higher temperatures for handling operations at room temperature and refueling operations.
\end{abstract}

\title{
1.0 Introduction
}

Ferritic alloys exhibit ductile fracture behavior at high temperatures but will fail by brittle fracture at lower temperatures. The temperature where the ductile-brittle transition takes place is called the ductile-brittle transition temperature (DBTT). With this transition behavior the fracture toughness of ferritic alloys can change drastically over a small temperature range near the DBTT. Experimental evidence shows that the DBTT is raised by loading rate and neutron irradiation. This ductile-brittle transition phenomenon has long been a great concern for nuclear reactor designers and has discouraged high neutron fluence applications of ferritic alloys. It was not until austenitic stainless steels were found to swell at an unacceptable level that the interest in the alloys was resumed. Several reactor experiments have shown that ferritic alloys exhibit excellent resistance to void swelling. The materials were therefore chosen as the candidate materials for LMR cladding and duct. However, their susceptibility to brittle failure at low service temperature calls for the transition behavior studies by performing impact tests. Charpy specimens (small notched bars) miniaturized for irradiation experiments and duct sections were impacted to measure the fracture energy.

Another concern for ferritic alloys is the microstructural stability under neutron irradiation. The following section presents microstructural examination of HTg. 


\subsection{MICROSTRUCTURE}

Heat treatment controls the microstructure and mechanical properties of HT9. For example, the refinement of the prior austenite grain (PAG) size lowers the DBTT, and the presence of delta ferrite reduces the material strength. HT9 was austenitized in the temperature range of 1035 to $1050{ }^{\circ} \mathrm{C}$ to minimize the formation of delta ferrite, dissolve carbide precipitates into solution, and reduce the prior austenite grain size. As can be seen in Figure la, no PAG structure was evident below $1050^{\circ} \mathrm{C}$. At $1050^{\circ} \mathrm{C}$ and above (Figure 1b) the PAG structure became evident as did the martensite subgrain structure.

Prolonged exposure to neutron fluence induces microstructural instability in structural alloys and causes material problems such as void swelling, enhanced creep, and embrittlement. Because heat treatment and chemical

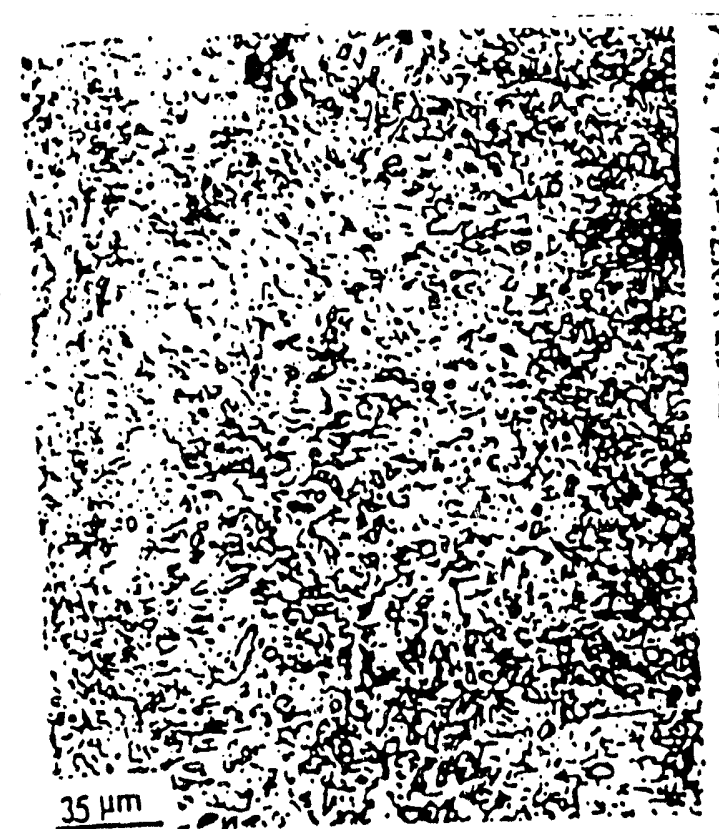

(a)

79321

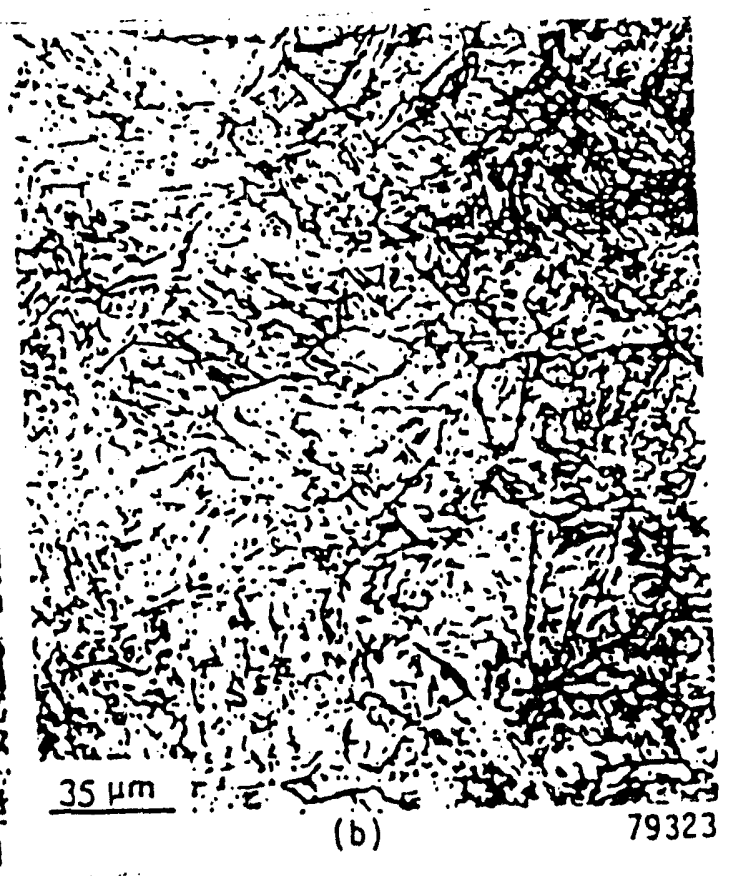

Figure 1 Optical micrographs of austenitizing treatment of HTg (a) $1000^{\circ} \mathrm{C} / 5 \mathrm{~min} / \mathrm{AC}$; (b) $1050^{\circ} \mathrm{C} / 5 \mathrm{~min} / \mathrm{AC}$. 
composition also control the microstructure of ferritic alloys, the effects of heat treatment and composition as well as irradiation conditions on the fracture behavior of ferritic alloys were investigated.

The microstructures observed in HT9 irradiated to high fluence in the temperature range $400^{\circ} \mathrm{C}$ to $650^{\circ} \mathrm{C}$ were found to be unaffected by irradiation damage. Precipitation characteristics in HTg can be classified according to three temperature regimes: $650^{\circ} \mathrm{C}, 540^{\circ} \mathrm{C}$ to $480^{\circ} \mathrm{C}$, and $425^{\circ} \mathrm{C}$ to $400^{\circ} \mathrm{C}$. TEM observations were performed on HTg specimens irradiated at $427^{\circ} \mathrm{C}$ and $510^{\circ} \mathrm{C}$ in the AA-I test, Capsule B-113, in EBR-II. Surprisingly, there was no void in either specimen that was irradiated to a fluence of $5.0 \times 10^{22} \mathrm{n} / \mathrm{cm}^{2}$ ( $E$ > $0.1 \mathrm{MeV})$. The elongated martensite laths with $\mathrm{M}_{23} \mathrm{C}_{6}$ precipitates along the boundaries were found in both $427^{\circ} \mathrm{C}$ and $510^{\circ} \mathrm{C}$ irradiated specimens. A fine precipitate phase was observed in the $427^{\circ} \mathrm{C}$ specimen which was not present in unirradiated specimens or the $510^{\circ} \mathrm{C}$ irradiated specimen. This fine precipitate phase (Figure 2) was identified as G-phase, a face-centered cubic (fcc) nickel silicide commonly found in irradiated austenitic stainless steels $[1]$.

\subsection{High Temperature Phase}

In the high temperature regime, increases in precipitate density and volume fraction are not notable. The behavior can best be described as a continuation of the martensite tempering treatment. The pre-irradiation

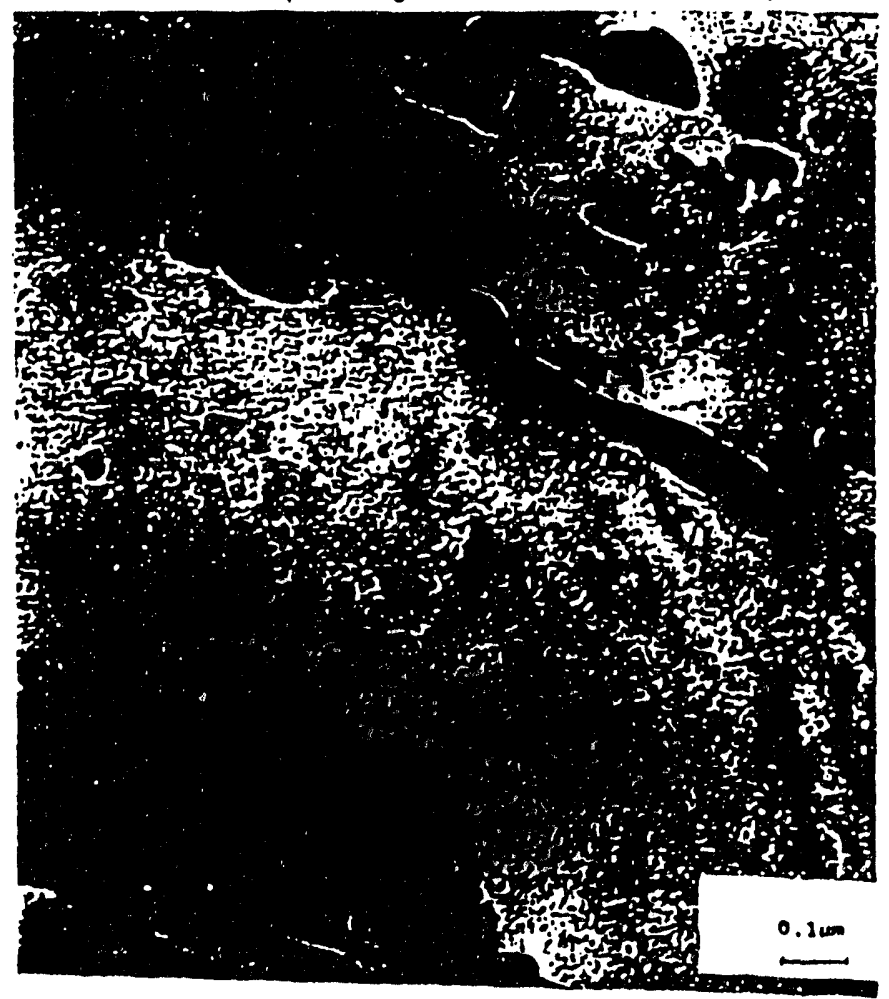

Figure 2 Micrograph showing fine precipitates phase in HTg irradiated at $427^{\circ} \mathrm{C}$. 
microstructural features such as grain boundary and subgrain boundary structures, dislocation configurations, and $\mathrm{M}_{23} \mathrm{C}_{6}$ precipitates are altered only slightly. Examples are provided in Figure 3 . It can be seen from this figure that the lath subgrain structure that was generated from tempered martensite is retained over the entire temperature range. In the specimen irradiated at $650^{\circ} \mathrm{C}, \mathrm{M}_{23} \mathrm{C}_{6}$ precipitate growth was most pronounced, and the subgrain size had increased to approximately one micron (1000 nm).

\subsection{Low Temperature Phase.}

The phases in neutron irradiated HTg were analyzed using energydispersive $x$-ray (EDX) microanalys is and selected area electron diffraction methods. Equiaxed particles averaging about $15 \mathrm{~nm}$ in diameter were found in an ÁA-I specimen irradiated at $425^{\circ} \mathrm{C}$ to a fluence of $12.2 \times 10^{22} \mathrm{n} / \mathrm{cm}^{2}$ (E>0.1

$\mathrm{MeV})$. X-ray microanalysis showed that these particles contained about $75 \mathrm{wt} . \%$ chromium and $13 \%$ molybdenum, with smaller amounts of iron and silicon. The small particles were identified as $\alpha^{\prime}$, the chromium-rich solid solution formed by phase separation in $\mathrm{Fe}-\mathrm{Cr}$ binary alloys [1]. Radiation-induced dislocation loops and tangles were identified in specimens irradiated at temperatures of 400 to $425^{\circ} \mathrm{C}$.

A second type of precipitate that appears as hexagonal-shaped, 30 to $60 \mathrm{~nm}$ sized particles on the carbide extraction replicas, was identified by single crystal electron diffraction as bcc $x$-phase. This irradiation-induced phase, which predominates in a specimen irradiated at $450^{\circ} \mathrm{C}$ to $9.7 \times 10^{22} \mathrm{n} / \mathrm{cm}^{2}$, is high in $\mathrm{Cr}, \mathrm{Fe}, \mathrm{Ni}$, and $\mathrm{Si}$ and contains relatively little Mo compared to thermally-induced $x$. The previously unidentified patterns were found to be consistent with a $f c c$ precipitate having a lattice parameter of $1.11 \mathrm{~nm}$. The particles were identified as G-phase formed in HTg irradiated to fluences as low as $2 \times 10^{22} \mathrm{n} / \mathrm{cm}^{2}$. As the fluence was increased to $9.7 \times 10^{22} \mathrm{n} / \mathrm{cm}^{2}$, no Gphase but a high density of $x$-phase was found, indicating that the G-phase was replaced by chi at longer times or higher fluences in the reactor.

Microstructural and precipitate characterization of HT9 were performed on specimens irradiated in the EBR-II (the AA-I experiment) to as high as $2.5 \times$ $10^{23} \mathrm{n} / \mathrm{cm}^{2}$ ( $E>0.1 \mathrm{MeV}$ ) as shown in Figure 4 . No void swe $11 \mathrm{ing}$ was observed under this irradiation condition [2]. Studies on the swelling behavior of 9$12 \mathrm{Cr}$ ferritic-martensitic steels irradiated in Phenix also reported that these steels swell very $1 \mathrm{ittle}$ and no voids were observed in alloy HT9 [3]. $\alpha^{\prime}, G$, and $x$ precipitates formed in the matrix at 400 and $427^{\circ} \mathrm{C} . \mathrm{M}_{23} \mathrm{C} 6$ was the major precipitate in HT9 at all temperatures and formed mainly at the lath boundaries. Dislocation configurations with radiation produced loops and tangles were only identified in the specimens irradiated at the temperatures of 400 to $425^{\circ} \mathrm{C}$. The microstructure examination showed that HTg was microstructurally stable under high fluences up to $2.5 \times 10^{23} \mathrm{n} / \mathrm{cm}^{2}$. 


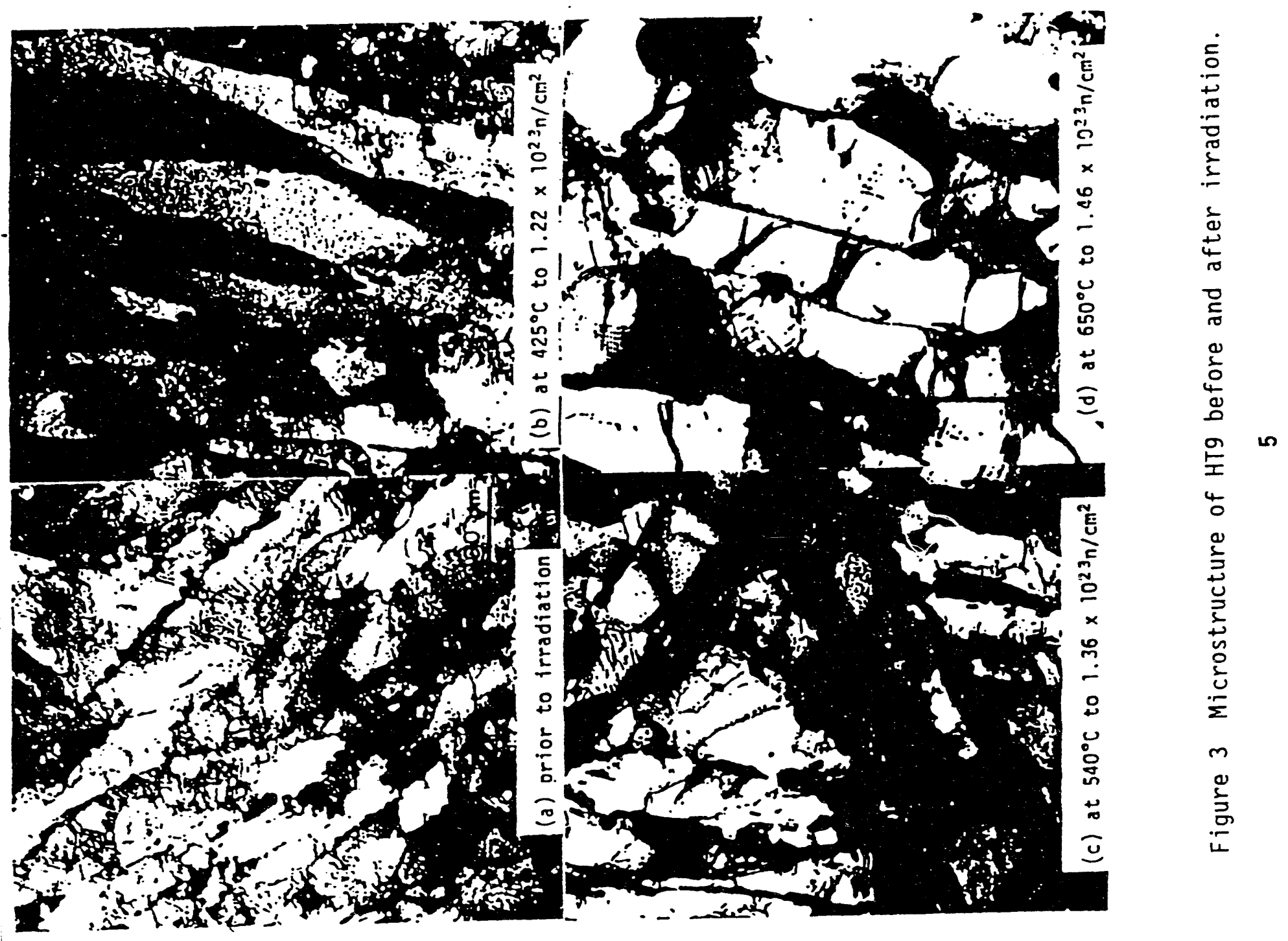


WHC-SA-2512-FP

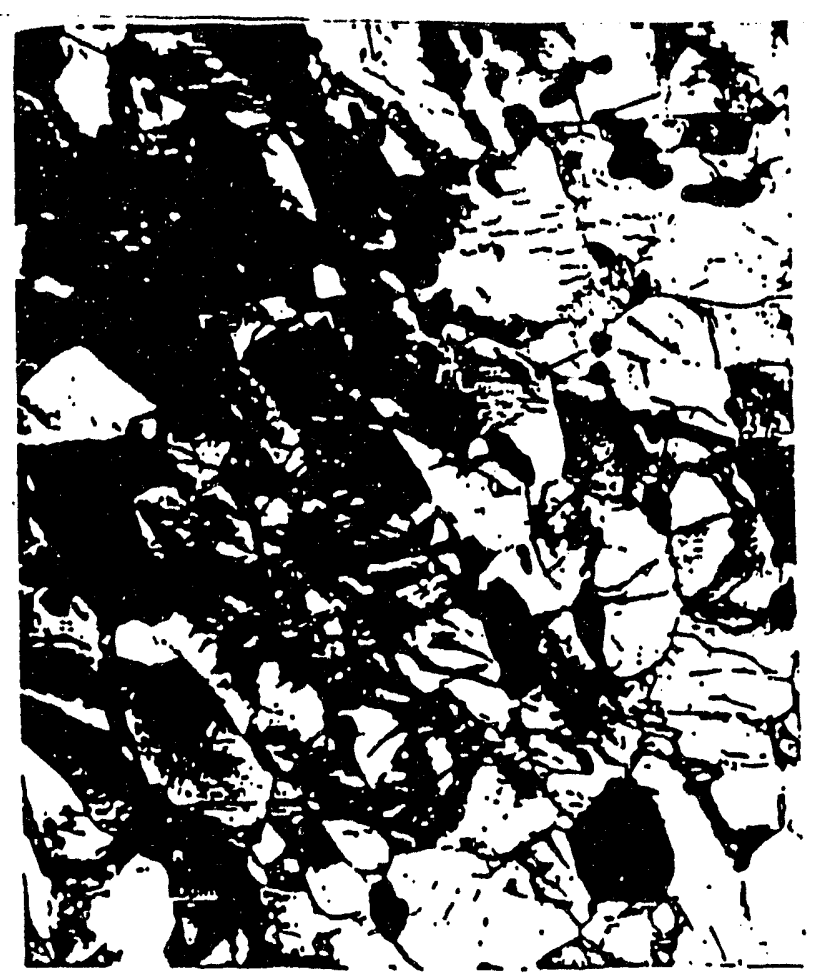

Figure 4 Microstructure in wrought HT9 specimen irradiated at $595^{\circ} \mathrm{C}$ to a fluence of $2.53 \times 10^{23} \mathrm{n} / \mathrm{cm}^{2}$.

\subsection{CHARPY IMPACT TESTING}

\subsection{Specimen Preparation}

The fracture energy of a Charpy specimen is specimen size dependent. The DBTT determined from a smaller Charpy specimen is lower than that of a larger specimen. For this reason, ASTM Standard E23-92 recommends a standard Charpy $v$-notch (CVN) specimen size: $10 \mathrm{~mm}$ square and $55 \mathrm{~mm}$ long with a $45^{\circ}$. $2 \mathrm{~mm}$ deep notch. During testing, the specimen is transferred from a furnace or a cooler to the test position and impacted rapidly in three point bending by a moving mass of known kinetic energy. The DBTT of the material is determined from the fracture energy required to break the specimen over a range of temperatures.

A one-half size Type A CVN specimen was chosen for irradiation studies. The length of the half size Charpy specimen could not be scaled down to 27.5 $\mathrm{mm}$ because of irradiation vehicle constraints. In addition, the notch dimensions were reduced from the standard dimensions in order to increase the constraint at the notch tip. The volume of eight half size Charpy specimens is equal to that of one standard CVN specimen. It usually takes eight specimens to define the entire DBTT curve. Although the fracture energy of a Charpy specimen is size dependent, the shift in DBTT following irradiation has been found to be independent of specimen size. Miniature Charpy specimens 
thus can be used to evaluate the effect of irradiation on fracture behavior for ferritic alloys.

\subsection{Experimental Procedures}

The impact testing system includes a drop tower, a specially designed temperature conditioning chamber, a specimen transfer device which permits remote testing of miniature Charpy specimens, and a digital oscilloscope. The drop tower requires less floor space for hot cell testing applications and is flexible for testing various specimen geometries. The specimen is placed on a set of anvils with a span of four times the specimen width [4].

- The testing system was automated to handle irradiated samples remotely. During the testing period, the instrumented tup and the impact velocity were checked daily. Typical. load trace data show that the precracked specimen display a clear peak load while the notched specimen does not. The data were digitized and processed with a computer to calculate the fracture energy.

\subsection{Results and Discussion}

The WHC miniature Charpy specimens were irradiated in the EBR-II to fluences of $3 \times 10^{22}$ and $6 \times 10^{22} \mathrm{n} / \mathrm{cm}^{2}(E>0.1 \mathrm{MeV})$. The material, heat number, fluence, and heat treatment are listed in Table 1. The transition curves of HT9 annealed at a lower temperature are shown in Figure 5. Irradiation at higher temperatures $\left(450-550^{\circ}\right)$ causes a less significant shift in DBTT in this material than the one annealed at a higher temperature. The DBTT of HT9 modified is lower than that of HTg as shown in Figure 6 . Higher

Table 1 Summary of heat treatment for irradiated Charpy specimens.

\begin{tabular}{|c|c|c|c|c|}
\hline Material & $\begin{array}{l}\text { Heat } \\
\text { No. }\end{array}$ & Heat treatment & $\begin{array}{l}\text { Fluence } \\
\left(10^{22} \mathrm{n} / \mathrm{cm}^{2}\right)\end{array}$ & Ref. \\
\hline $\begin{array}{l}\text { HTg } \\
9 \mathrm{Cr} r-1 \mathrm{Mo}\end{array}$ & $\begin{array}{l}91354 \\
30176\end{array}$ & $\begin{array}{l}1149^{\circ} \mathrm{C} / 1 \mathrm{~h}+760^{\circ} \mathrm{C} / 1 \mathrm{~h} / \mathrm{AC} \\
1038^{\circ} \mathrm{C} / 0.5 \mathrm{~h} / \mathrm{AC}+ \\
760^{\circ} \mathrm{C} / 0.5 \mathrm{~h} / \mathrm{AC}\end{array}$ & $\begin{array}{l}3 \\
3\end{array}$ & 4 \\
\hline HTg & 91353 & $\begin{array}{r}1038^{\circ} \mathrm{C} / 10 \mathrm{~min} / \mathrm{AC}+ \\
760^{\circ} \mathrm{C} / 30 \mathrm{~min} / \mathrm{AC}\end{array}$ & 3 & 5 \\
\hline HT9 Mod. & $\begin{array}{c}\text { ESR XA- } \\
3607\end{array}$ & $\begin{array}{l}1050^{\circ} \mathrm{C} / 0.5 \mathrm{~h} / \mathrm{AC}+ \\
780^{\circ} \mathrm{C} / 1.5 \mathrm{~h} / \mathrm{AC}\end{array}$ & 3 & 5 \\
\hline HT9 & 91354 & $1149^{\circ} \mathrm{C} / 1 \mathrm{~h}+760^{\circ} \mathrm{C} / 1 \mathrm{~h} / \mathrm{AC}$ & 6 & 6 \\
\hline $9 \mathrm{Cr}-1 \mathrm{Mo}$ & 30182 & $\begin{array}{r}1038^{\circ} \mathrm{C} / 1 \mathrm{~h} / \mathrm{AC}+ \\
760^{\circ} \mathrm{C} / 1 \mathrm{~h} / \mathrm{AC}\end{array}$ & 6 & 6 \\
\hline
\end{tabular}




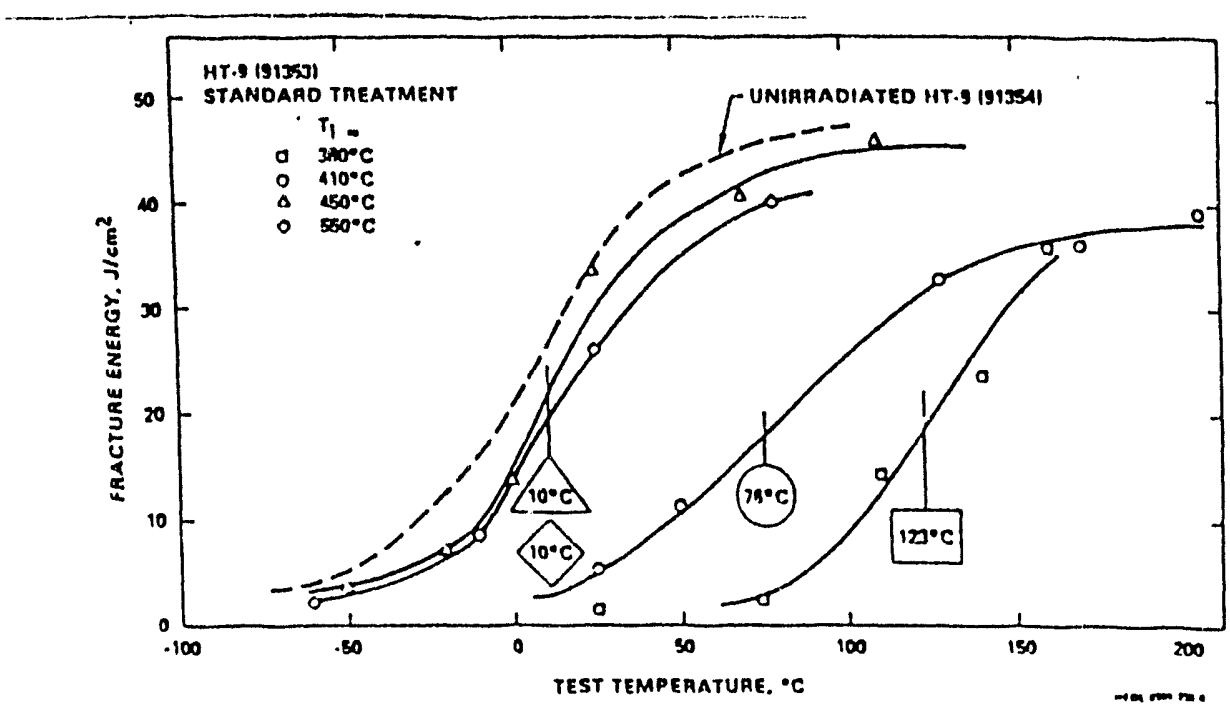

Figure 5 Charpy transition curves for HT9 (91353) Irradiated to $3 \times 10^{22} \mathrm{n} / \mathrm{cm}^{2}(E>0.1 \mathrm{MeV})$.

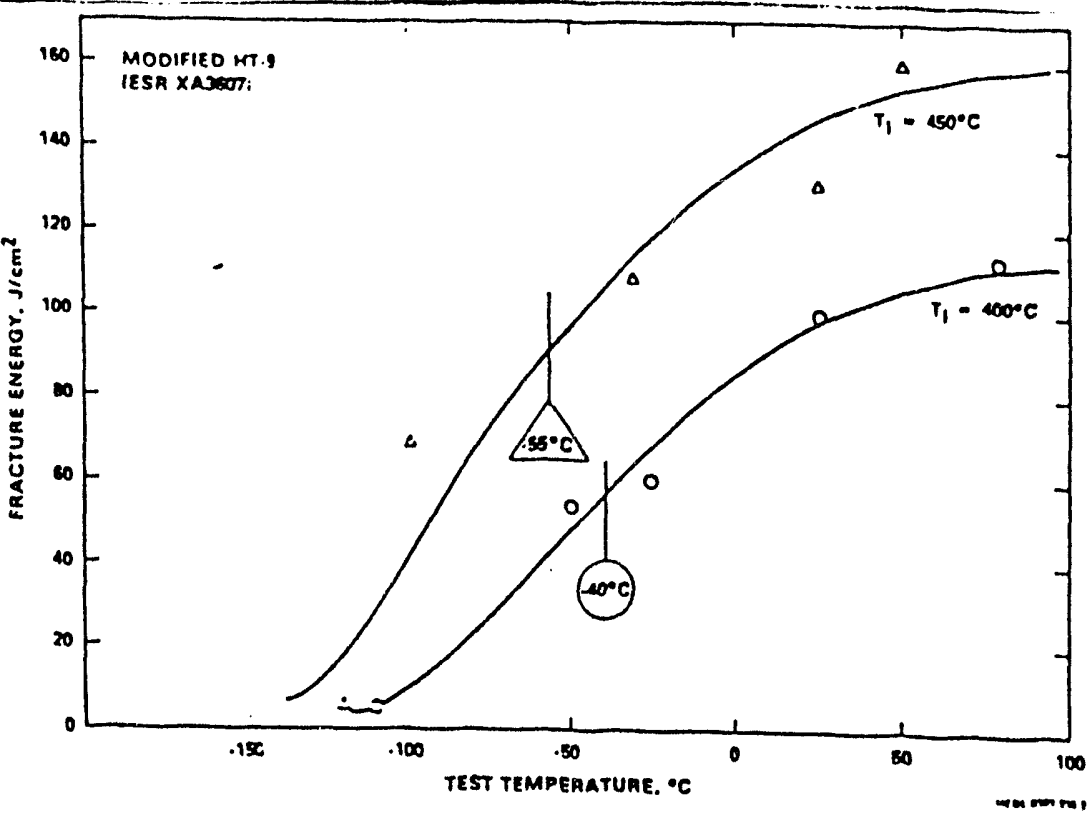

Figure 6 Charpy transition curves for HTg modified irradiated to $3 \times 10^{22} \mathrm{n} / \mathrm{cm}^{2}(E>0.1 \mathrm{MeV})$. 
fluence results are reported in Ref. 6 for Charpy test results of HT9 and $9 \mathrm{Cr}-$ Mo irradiated to a fluence of $6 \times 10^{22} \mathrm{n} / \mathrm{cm}^{2}$. The DBTT is expected to shift upward with irradiation. However, a comparison between these results indicates little effect of irradiation on the values of DBTT for HT9. DBTT values obtained from irradiated Charpy specimens of HTg are given in Table 2 $[5,6]$.

Table 2 Charpy impact data for irradiated HT9

\begin{tabular}{ccc}
\hline $\begin{array}{c}\text { Irradiation } \\
\left({ }^{\circ} \mathrm{C}\right)\end{array}$ & $\begin{array}{c}\text { Fluence } \\
\left(10^{22} \mathrm{n} / \mathrm{cm}^{2}\right)\end{array}$ & $\begin{array}{c}\text { DBTT } \\
\left({ }^{\circ} \mathrm{C}\right)\end{array}$ \\
\hline & & \\
419 & 1.1 & 108 \\
410 & 2.1 & 76 \\
450 & 2.1 & 10 \\
550 & 2.1 & 10 \\
380 & 2.3 & 123 \\
428 & 3.1 & 75 \\
424 & 4.5 & 90 \\
392 & 4.8 & 150 \\
398 & 5.9 & 125 \\
390 & 7.0 & 150 \\
42.5 & 7.0 & 50 \\
400 & 8.0 & 100 \\
405 & 9.0 & 75 \\
\hline
\end{tabular}

\subsection{DUCT SECTION IMPACT TESTING}

Because HTg exhibits the ductile-brittle transition behavior as revealed by Charpy impact testing, the integrity of a ferritic duct under impact loading, possibly caused by an accident, must be demonstrated. Accordingly, impact type tests on sections of an unirradiated HT9 FFTF duct were conducted at low temperatures in order to study brittle fracture in duct components.

\subsection{Specimen Preparation}

A FFTF subassembly duct of HT9 has a hexagonal cross section with rounded corners as shown in Figure $7 \mathrm{a}$. One-inch $(25.4 \mathrm{~mm})$ wide sections were cut from an FFTF duct (Heat No. 84425). Notches were machined at one corner of the duct specimens along the axial direction to depths of $0.25,0.51,1.02$, and 1.52 $\mathrm{mm}$. The radius at the notch tip was $0.076 \mathrm{~mm}(0.003 \mathrm{inch})$. Most of the duct specimens had a notch of uniform depth along the axial direction except for four specimens. The four remaining specimens had an inclined notch depth as shown in Figure $7 b$. 


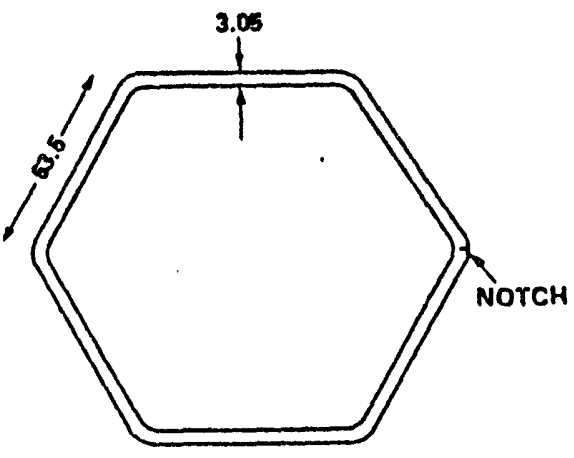

(a)

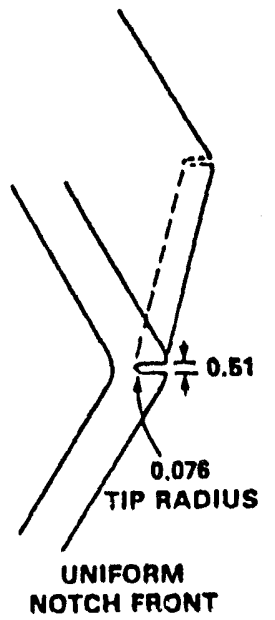

NOTCH FRON

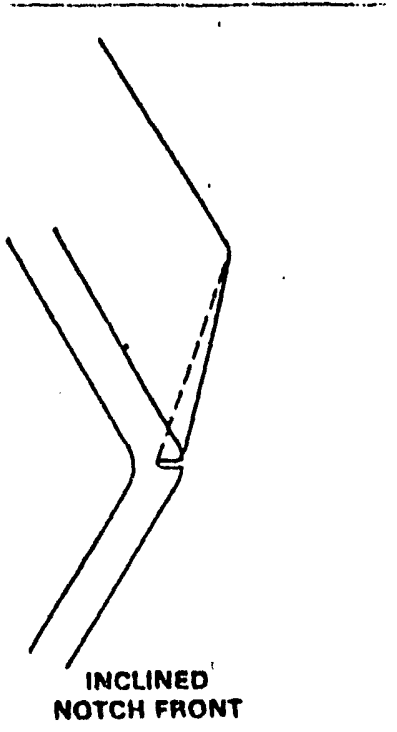

(b)

Hat mowen.

Figure 7 (a) cross section of FFTF subassembly duct; (b) notch at a hexcan corner.

\subsection{Experimental Procedures}

The impact testing system is the same as the one used for charpy testing steel striker was attached to the instrument tup assembly a mustem was used to cool the duct sample temperature (Figure 8). Testing was performed over the temperature range of -6 to $-60^{\circ} \mathrm{C}$. Each test specimen was immersed in the bath of the cooling system, equilibrated, and quickly transferred to a Dynatup drop tower for impact testing. The duct specimen was placed in a recess with the notched corner positioned halfway between the two impacted duct flats. When the crosshead was released, it fell along guide columns and impacted the specimen. The load-time history was transmitted to a digital oscilloscope, and the velocity of the tup was measured on a digital oscilloscope by recording the time of travel of a flag on the crosshead falling through an infrared sensor. After the impact test, the notched corner of the specimen was cut off and heat tinted at $500^{\circ} \mathrm{C}$ for one hour. The fracture surfaces were examined by a scanning electron microscope model JSM-35C operating at $25 \mathrm{kV}$ for fracture mode determination.

\subsection{Results and Discussion}

Duct specimens were impacted at velocities from $4 \mathrm{~m} / \mathrm{sec}$ to $1.8 \mathrm{~m} / \mathrm{sec}$, with most of the specimens tested with a velocity of either $4 \mathrm{~m} / \mathrm{sec}$ or $2.3 \mathrm{~m} / \mathrm{sec}$. A total of 15 duct samples with notch depths ranging from $0.25 \mathrm{~mm}$ to $1.52 \mathrm{~mm}$ and inclined depth from 0 to $1.5 \mathrm{~mm}$ were impacted at various velocities. 


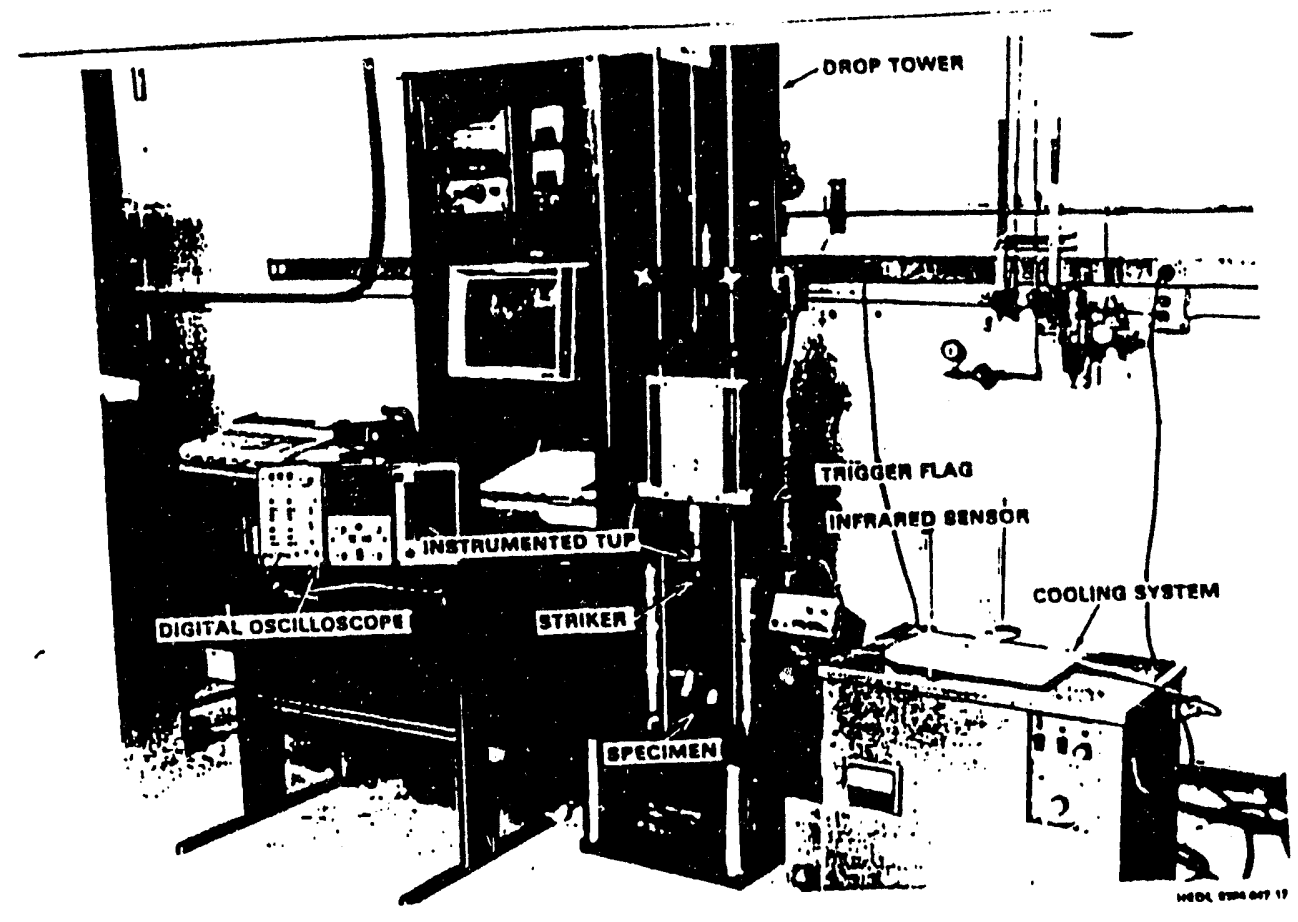

Figure 8 Test Apparatus for duct section impact testing.

\subsubsection{Absorbed Energy}

Since the duct specimen did not exhibit total failure, the total energy of the falling crosshead was absorbed by the duct specimen during the impact. The energy absorbed by the duct specimen up to the point of sudden load drop represents the susceptibility of a flawed duct to the initial cracking. During impact, the specimen absorbs the change in kinetic energy before and after initial contact between the specimen and the tup. From the basic law of physics that the impulse within a short time, $\int_{0}^{t} p d t$, is equal to the momentum change, the absorbed energy, $\Delta W$, is calculated through the following equation:

$$
\Delta W=W\left(1-W / W_{0}\right)
$$

$$
\text { where } \begin{aligned}
W_{0} & =m V_{0}^{2} / 2 \\
m & =\text { mass } \\
V_{0} & =\text { initial impact velocity } \\
W^{\prime} & =V_{0} \int_{0}^{t} p d t \\
p & =10 a d \\
t & =\text { time. }
\end{aligned}
$$


To estimate the work done in the vicinity of the crack tip prior to crack initiation, let's consider the notched section of the duct subjected to a bending moment, $M$, and an angular displacement, $\theta$, as shown in Figure 9 . The work done at the vicinity of the notch root is

$$
\begin{aligned}
W_{r} & =\int_{0 \theta} M d \theta \\
& =\int_{0}^{\theta} \frac{p l}{2} \cos 60^{\circ} d \theta
\end{aligned}
$$

For small deflection,

$$
\mathrm{d} \theta \simeq \frac{\mathrm{d} \delta}{\ell}=\frac{\mathrm{V}_{\mathrm{o}}}{2 \ell} \mathrm{dt}
$$

From Equations 2 and 3 we obtain

$$
\int W_{r}=\frac{V_{0}}{8} 0^{t} p d t
$$
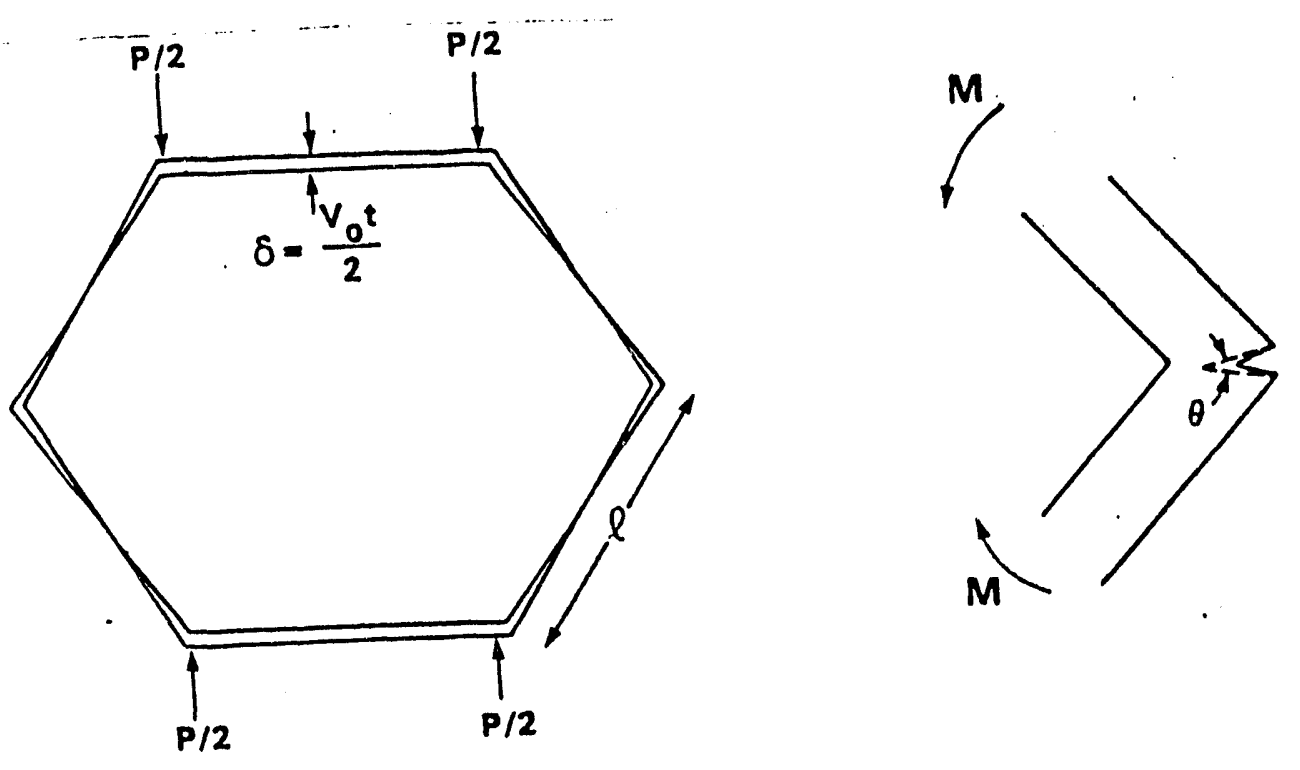

HEDL EMAOTt.2

Figure 9 The configurations of the deformed duct section and crack profile. 
The absorbed energy $\left(\Delta W_{m}\right)$ to the maximum load at the crack tip in Table 3 was calculated with Equations 1 and 4 over the time period 0 to $t_{\max }$ (the time when the maximum load is reached). It should be noted that in the foregoing analysis, the load applied across the flats of the duct is approximately two equal concentrated loads at the opposite corners for simplicity. The typical load-time traces of the tested duct specimens are shown in Figures 10 (high velocity and deep notch) and 11 (low velocity and inclined notch). For specimens having a shallow notch impacted at a high velocity, the sudden load drop was not clearly observed, and no crack extension in the duct specimens of $0.25 \mathrm{~mm}$ notch depth was found by heat tinting. The energy absorption up to 3 milliseconds after impact was nevertheless calculated for comparison.

- The maxinum load and the energy absorbed by the duct section up to the maximum load are plotted in Figures 12 and 13. As seen in these figures, the absorbed energy is dependent of temperature linearly over the test temperature range, but the maximum load is not. This is because the impact object is a complicated configuration consisting of six flats and six corners. The assumption that the crack initiation occurs at the maximum load may not be correct. The maximum load could be attained before or after crack initiation depending on deformation in the top and bottom flats or effects of inertial oscillation. On the other hand, the absorbed energy, calculated from the area

Table 3 Impact test results for HT9 duct

\begin{tabular}{lccccr}
\hline $\begin{array}{l}\text { Test } \\
\text { depth }\end{array}$ & $\begin{array}{c}\text { temp. } \\
(\mathrm{mm})\end{array}$ & $\begin{array}{c}\text { Max. } \\
\text { Velocity } \\
(\mathrm{m} / \mathrm{sec})\end{array}$ & $\begin{array}{c}\text { load } \\
(\mathrm{kg})\end{array}$ & $\begin{array}{l}\Delta \mathrm{W}_{\mathrm{m}} \\
(\mathrm{J})\end{array}$ & $\begin{array}{c}\mathrm{K}_{\mathrm{c}} \\
(\text { MP } \mathrm{C}(\mathrm{m})\end{array}$ \\
\hline 0.51 & -6 & 4.0 & 861.4 & 14.90 & 131.6 \\
0.51 & -25 & 4.0 & 768.4 & 12.50 & 184.4 \\
0.51 & -36 & 4.0 & 867.1 & 11.60 & 113.2 \\
0.25 & -60 & 4.0 & 857.5 & 9.39 & 235.7 \\
& & & & & \\
1.27 & -6 & 3.4 & 660.2 & 3.91 & 122.8 \\
1.02 & -25 & 4.0 & 796.2 & 7.20 & 145.4 \\
1.27 & -36 & 4.0 & 797.6 & 4.33 & 108.0 \\
1.52 & -60 & 4.0 & 627.8 & 2.87 & 87.3 \\
1.02 & -6 & 2.3 & 485.8 & 4.26 & 99.8 \\
1.52 & -25 & 2.5 & 354.3 & 2.83 & 77.0 \\
1.52 & -36 & 2.3 & 522.3 & 1.84 & 73.9 \\
1.52 & -42 & 2.3 & 412.8 & 1.70 & 58.3 \\
& & & & & 127.4 \\
$0-1.52$ & -6 & 2.3 & 479.9 & 6.79 & 82.9 \\
$0-1.52$ & -36 & 2.5 & 503.5 & 5.48 & 105.7 \\
$0-1.52$ & -60 & 1.8 & 462.7 & 2.84 & 82.9 \\
\hline
\end{tabular}

Notch 
Figure 10 Load-time history for HTg duct sections tested at $-60^{\circ} \mathrm{C}$ (Curve A) and $-25^{\circ} \mathrm{C}$ (Curve $\mathrm{B}$ ).
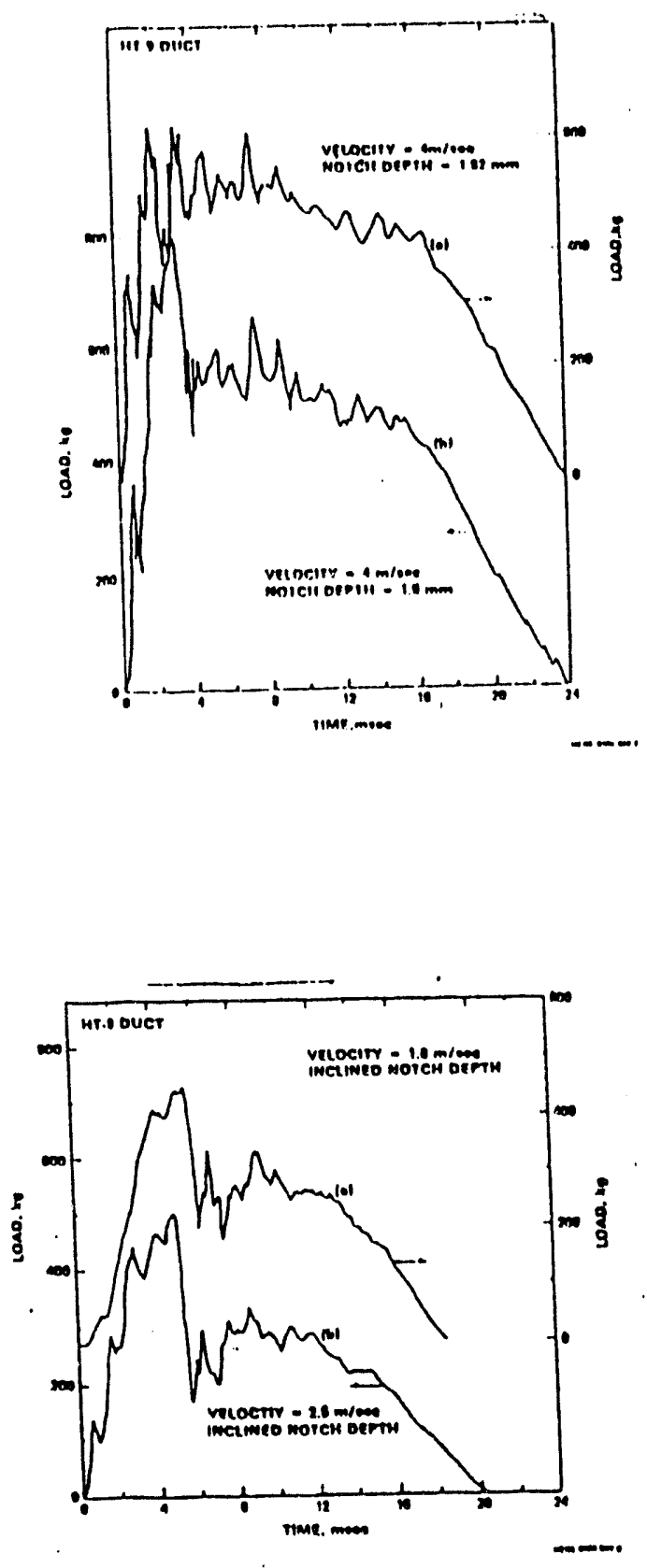

Figure 11 Load-time history for HT9 duct sections tested at $-60^{\circ} \mathrm{C}$ (curve $A$ ) and $-36^{\circ} \mathrm{C}$ (curve $B$ ). 


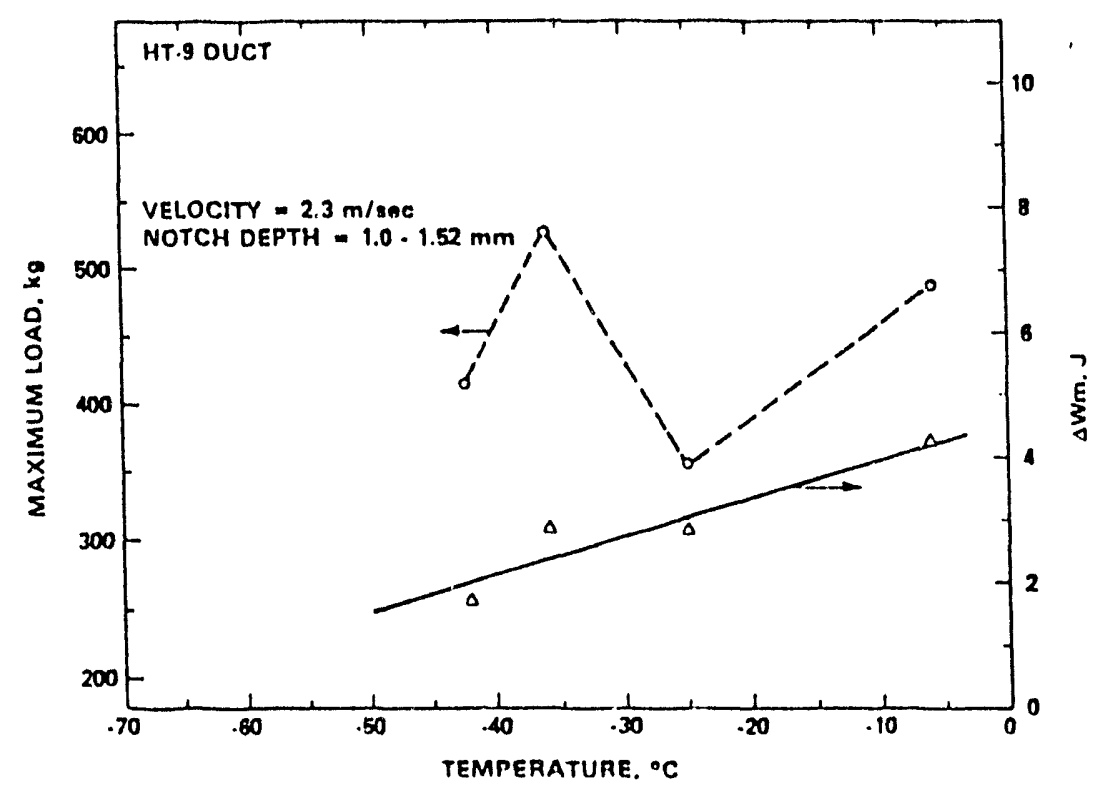

Figure 12 Temperature Dependence of Maximum Load and Absorbed Energy for Duct Specimens of Deep Notch Tested at $2.3 \mathrm{~m} / \mathrm{sec}$.

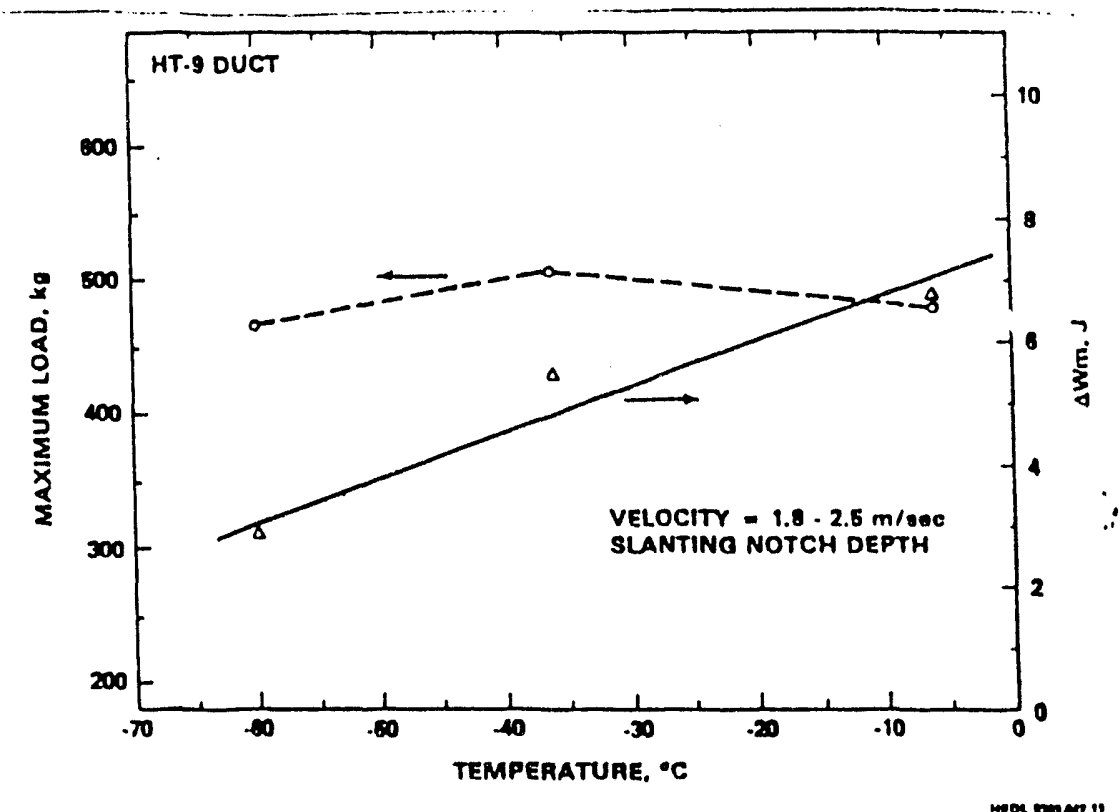

Figure 13 Temperature dependence of maximum load and absorbed energy for duct specimens of inclined notch tested at $2.3 \mathrm{~m} / \mathrm{sec}$. 
under the load-time curve, represents the ability of the material to resist failure at various degrees of embrittlement.

\subsection{2 $K_{c}$ Estimated From Maximum Load}

The strength of the singularity at the tip of a crack can be raised by decreasing or increasing strain rate until it reaches the critical value and fast, brittle fracture will occur. The strength of the singularity at the crack tip is known as the stress intensity factor, $K_{1}$. For design safety concerns, the critical stress intensity factor $\left(K_{I c}\right)$ under plane strain conditions should be evaluated for the structural material, in order that the allowable stress level can be set to prevent the catastrophic failure of the duct.

An attempt was made to model a cracked midflat and a cracked corner for the $K_{1}$ calibrations of a LMR duct [7]. The midflat of a duct was assumed to behave like a cracked beam subjected to tension and bending while the cracked hexcan corner like an infinite strip loaded by concentrated forces. The need to use different models stems from the fact that the tensile stress near the hexcan corner is significantly laiger than that at the midflat owing to the curvature of the hexcan corner. The stress intensity values for LMR ducts with longitudinal corner cracks under internal pressure is given by

$$
K_{1}=\sigma /(\pi a) f
$$

where $f$ is a geometry factor, equal to 1 to 1.2 for crack depths up to $1.52 \mathrm{~mm}$ in a cracked hexcan corner of a $3.05-\mathrm{mm}$ thick duct. Assuming the rapid crack extension occurs at the maximum load, the critical stress intensity factor $\left(K_{c}\right)$ for each specimen can be calculated from Equation 5 . However, as shown in Figures 12 and 13 , there is no clear trend for the temperature dependence of maximum load, the values of $k_{c}$ for cracked corners of a duct estimated from the maximum load at various temperatures are expected to be trendless. Thus, the $K$ evaluation method for a cracked duct should involve absorbed energy, which reflects the effect of temperature better than the maximum impact load.

\subsection{3 $K_{c}$ Estimated From Absorbed Energy}

The stress intensity factor can be measured through the experimental determination of the energy release rate of the test configuration. The strain energy release rate with crack extension is given by [7] 


$$
G=\frac{q^{2}}{2} \frac{\partial c}{\partial a}
$$

where $q$ is the applied force per unit thickness, $c$ is the total compliance of the specimen per thickness, and a is crack length. The strain energy in the body is the work done in loading:

$$
\Delta W=\frac{q \delta}{2}=\frac{c q^{2}}{2}
$$

The $K_{1}$ ad $G$ have the following relationship:

$$
K_{1}=\sqrt{\left(\frac{E G}{1-V^{2}}\right)}
$$

Combining Equations 6,7 , and 8 leads to

$$
K_{1}=\int\left[\frac{E \Delta W}{\left(1-V^{2}\right) c} \frac{\partial c}{\partial a}\right]
$$

To compute the derivative in Equation 9 , a series of measurements of compliance, as a function of crack length, is needed. The critical stress intensity factor of the duct can now be obtained by calculating the system energy absorbed up to the maximum load and the compliance from load-time records. In evaluating the compliance (c) the measure-ments were made in the essentially elastic range, where the displace-ments determined from load-time records and negligible machine para-meters [9] were recoverable on loading. The derivative, dc/da, was estimated from several specimens having various initial notch depths. The values of $c$ for specimens tested at $-36^{\circ} \mathrm{C}$ were 7.84 $\times 10^{-3}, 9.80 \times 10^{-3}$, and $11.76 \times 10^{-3} \mathrm{~mm} / \mathrm{kg}$ for notch depths of $0.25,0.51$, and $1.27 \mathrm{~mm}$, respectively. The value of $\mathrm{dc} / \mathrm{da}$ was estimated to be $3.84 \times 10^{-3} / \mathrm{kg}$. These values were used for all specimens tested under different conditions, because it was difficult to produce accurate results for high velocity tests. With $E=2.07 \times 10^{5} \mathrm{MPa}$ and $v=0.2$, the values of $K_{c}$ are estimated and 1 isted in Table 3.

The temperature dependence of $K_{c}$ for deeply cracked duct sections of HT9 impacted at $4.0 \mathrm{~m} / \mathrm{sec}$ and $2.3 \mathrm{~m} / \mathrm{sec}$ is plotted in Figure 14 . As expected, the value of $K_{c}$ decreases with decreasing temperature. In addition, the results showed that the dynamic fracture toughness of the duct increased with increasing impact velocity. Crack extensions longer than $1.27 \mathrm{~mm}$ were revealed by heat tinting. The temperature dependence of dynamic fracture toughness for the HT9 duct tested at a lower impact velocity is consistent 


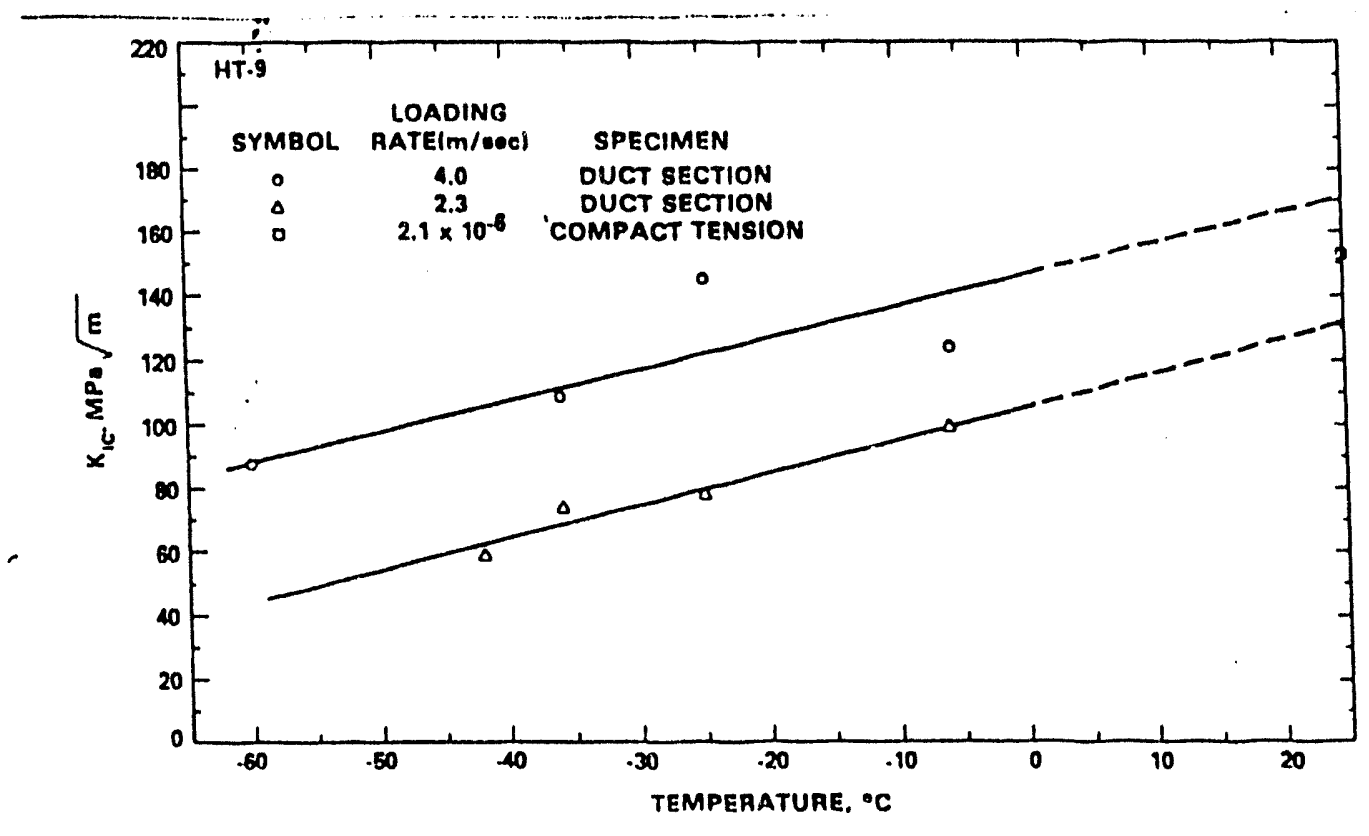

Figure 14 Temperature dependence of critical stress intensity factor estimated from absorbed energy.

with the static fracture toughness of HTg compact tension specimens as shown in Figure $15\left(K_{c}=152 \mathrm{MPa} / \mathrm{m}\right.$ at room temperature $)$ [10].

\subsubsection{Fracture Appearance Transition Temperature}

The fracture surfaces of four specimens were examined using a scanning electron microscope as shown in Figure 15 [11]. The test conditions for these four specimens are: $3.4 \mathrm{~m} / \mathrm{sec}$ at $-6^{\circ} \mathrm{C}, 4.0$ and $2.3 \mathrm{~m} / \mathrm{sec}$ at $-36^{\circ} \mathrm{C}$, and 1.8 $\mathrm{m} / \mathrm{sec}$ at $-60^{\circ} \mathrm{C}$. The fracture surface of the specimen tested at $-60^{\circ} \mathrm{C}$ was predominantly brittle, with only $14 \%$ ductile fracture consisting of a plastic stretch zone region approximately $0.19 \mathrm{~mm}$ and an unfractured ligament $0.23 \mathrm{~mm}$. The remainder of the fracture surface was brittle in appearance. In comparison, specimeris tested at higher temperatures contained smaller brittle fracture zones. In the case of the specimen tested at $-6{ }^{\circ} \mathrm{C}$, no areas showing a brittle fracture appearance could be identified. An increase in impact velocity for the $-36^{\circ} \mathrm{C}$ test temperature was found to increase the percent brittle fracture appearance only slightly from $61.5 \%$ to $72.0 \%$. Figure 16 provides a plot of percent ductile fracture appearance as a function of test temperature. Comparisons between Figures 5 and 16 demonstrate similar behavior. 
Figure 15 Fractographs of selected duct specimens for the test conditions shown. The machined notched towards the top $(x 43)$.

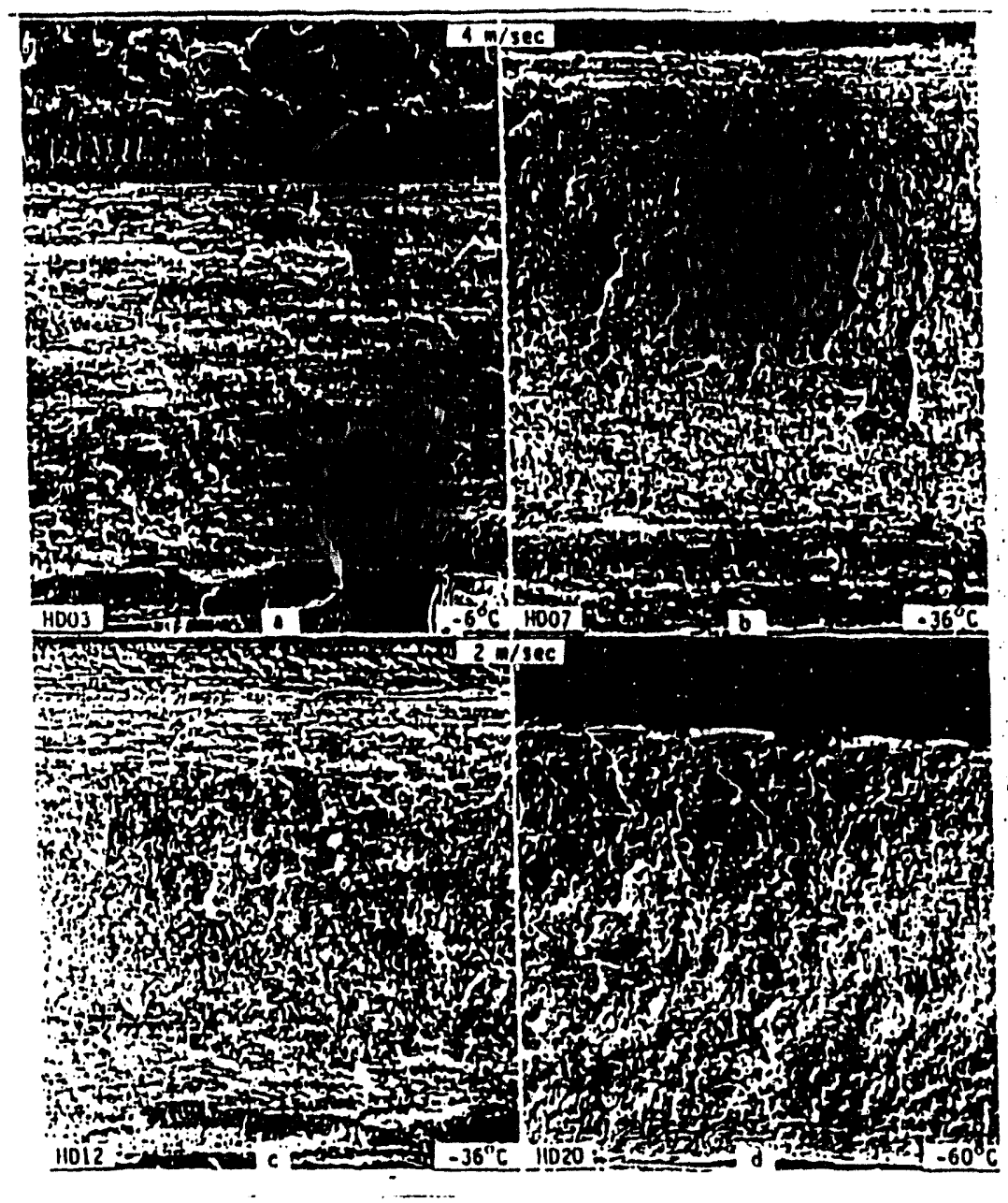

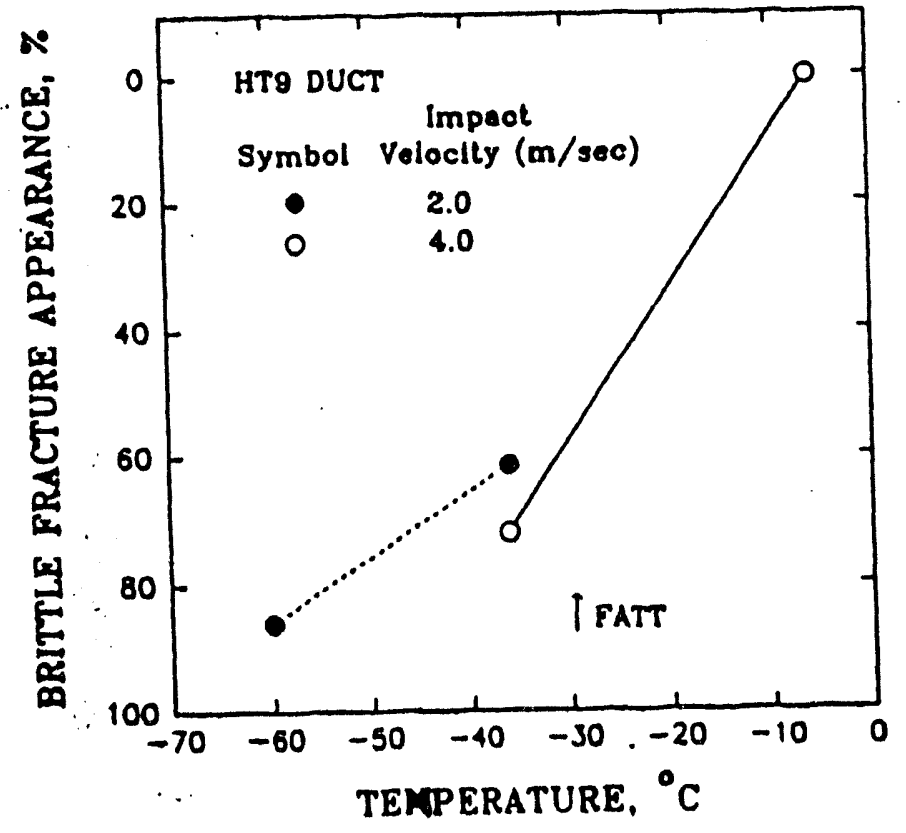

Figure 16 Determination of the FATT for unirradiated duct specimens. 
The portion of the impact energy absorbed in the cracked area of the duct will vary depending on the location of a crack in a duct. The fact that a deep crack at the corner of the duct does not penetrate through the wall thickness of the duct after being impacted by a maximum load of $635 \mathrm{~kg}$ at -60 ${ }^{\circ} \mathrm{C}$ suggests that HTg ducts have good fracture resistance. On the basis of these duct impact results, irradiated HTg duct sections are believed to have adequate fracture toughness at much higher temperatures for handling operations at room temperature and refueling operations.

\subsection{CONCLUSIONS}

The excellent resistance to void swelling exhibited by HTg has led to choosing ferritic alloys as candidate materials for fast and fusion reactor applications. Tive fracture surfaces of HT9 are examined by SEM. Experimental evidence has shown that the microstructure of the material remains stable after irradiation. Impact testing on FFTF duct sections of HTg indicates that HT9 ducts have adequate fracture toughness at much higher temperatures for handling operations at room temperature and refueling operations.

\section{REFERENCES}

1. D. S. Gelles and L. E. Thomas, "Effects of neutron irradiation on microstructure in experimental and commercial ferritic alloys," Proceedings of Topical Conference on Ferritic Alloys for Use in Nuclear Energy Technologies," Snowbird, Utah, 559 (1983).

2. W. J. S. Yang, G. M. Konze, and T. Lauritzen, "Microstructural examination of high fluence of HTg," Westinghouse Hanford Company, Richland, Washington, private communication, 1985.

3. P. Dubuisson, D. Gilbon, and J. L. Seran, "Microstructure evolution of ferritic-martensitic steels irradiated in the fast breeder reactor Phenix," J. of Nuclear Materials 205, 178 (1993).

4. W. L. Hu and D. S. Gelles, "Miniature Charpy impact test results for the irradiated ferritic alloys HTg and modified $9 \mathrm{Cr}-1 \mathrm{Mo}, "$ Proceeding of Topical Conference on Ferritic Alloys for Use in Nuclear Energy Technologies, Snowbird, UT, 631-646 (1984).

5. W. L. HU, "Charpy test results on HTg alloys irradiated in the AAXIV Phase II experiment," Westinghouse Hanford Company, Richland, Washington, private communication, 1983. 
6. W. L. Hu and D. S. Gelles, "The ductile-to-brittle transition behavior of martensitic steels neutron irradiated to $26 \mathrm{dpa}, "$ ASTM STP 956, 83-97 (1987).

7. H. J. Petroski and J. L. Glazik, "Effects of cracks in irradiationembrittlement hexagonal subassembly ducts," Nuclear Engineering and Design 49, 51-68 (1978).

8. G. R. Irwin and J. A. Kies, "Critical energy rate analysis of fracture strength," Welding Journal Research Supplement 33, 1935-1985 (1954).

9. D. R. Ireland, "Procedures and problems associated with reliable control - of the instrumented impact test," Instrumental Impact Testing, ASTM STP $563,3-29(1974)$.

10. F. H. Huang and G. L. Wire, "Fracture toughness testing on ferritc alloys using the electropotential techniques," Journal of Nuclear Materials 10 $1511-1516$ (1981).

11. F. H. Huang D. S. Gelles, "Impact testing of notched HTg FFTF duct sections," private communication, Westinghouse Hanford Company, Richland, Washington, 1983. 
WHC-SA-2512-FP

\section{DISTRIBUTION}

Number of Copies

ONSITE

Westinghouse Hanford Company

$$
\begin{aligned}
& \text { F. F. Huang } \\
& \text { Central Files } \\
& \text { Document Processing } \\
& \text { and Distribution } \\
& \text { Information Release } \\
& \text { Administration }
\end{aligned}
$$

